\title{
A Sermon for Yom Kippur Morning
}

\author{
October 1, 2006 \\ (On the $24^{\text {th }}$ anniversary of the 1982 war)
}

As he took the pulpit on the morning of Yom Kippur in 2006, Rabbi Beerman felt an ominous sense of familiarity. Twenty-four years earlier, he had given a sermon about the grave dangers lurking in Israel's first Lebanon War. His fears were not unfounded. That conflict lasted, in one form or another, for eighteen long and difficult years, during which time Lebanon devolved into civil war and the reputation of the Israeli army and state suffered.

In what would become a recurrent and haunting phrase that Beerman would utter from the Leo Baeck pulpit, he said, "Here we are again," referring not only to Yom Kippur, but also to another Israeli military engagement in Lebanon. A little more than two months earlier, on July 12, Israel responded to a rocket attack and the abduction of two of its soldiers by the Lebanese militia group Hezbollah with punishing aerial attacks and a ground incursion into southern Lebanon. Israel's aims were twofold: to attempt to degrade the offensive capacity of Hezbollah, which would send thousands of rockets during July and August into northern Israel (generating deep fear and even panic among its citizens); and to attack the civilian infrastructure of Lebanon, including Beirut, in order to pressure the government to bring Hezbollah to heel.

In seeking to fulfill these aims, the second Lebanon engagement became, according to Beerman, "but a new chapter for Barbara Tuchman's March of Folly," the 1984 book that explored the constant impulse of governments, from antiquity to the present, to act against their interests in undertaking military actions. Even more damaging than the conflict on the battlefield was the internal struggle-within Israel, the Diaspora community, and the Jewish soul. Beerman feared, as he had earlier, that the Jews, in Israel and beyond, had lost their moral compass. In his own immediate environs, he sharply criticized the Jewish communal organizations that condemned the 
decision of the Los Angeles County Human Rights Commission to bestow an award in September 1982 on his close friend the Muslim leader Dr. Maher Hathout. The groups believed that Dr. Hathout was too extreme in his criticism of Israel-including his assertion that the country was an apartheid state-a claim that Beerman sought to parry by referring to similar comments by Israeli public officials themselves.

These are the words of Nobel Laureate Pablo Neruda:

Now we will count to twelve and we will all keep still.

For once on the face of the earth let's not speak in any language, let's stop for one second and not move our arms so much. It would be an exotic moment without rush, without engines, we would all be together in a sudden strangeness.

... If we were not so single-minded about keeping our lives moving, and for once could do nothing, perhaps a huge silence / might interrupt this sadness of never understanding ourselves. Perhaps the earth can teach us / as when everything seems dead and then proves to be alive.

Now I'll count up to twelve and you keep quiet and I will go.

One-two-three-Maybe that's all this sermon requires, that and a deep breath. Maybe. But-you know how it is with rabbis, and especially on Yom Kippur.

When this day is over. When the gates of Yom Kippur are closed for another year. When the prayers and the music and the words spoken have fallen silent, we will all be, once again, alone, alone to face ourselves, to return again to what our lives are, and perhaps, to wonder what they mean. When I try to think of what my life is and was, when I wonder what it meant, the sad days passing, the dog sick and still waiting to be fed, the closeness of my wife sleeping, presences of our grown children and grandchildren, blessing them one by one on the Shabbat, listening as they sing with the guitar, or the youngest of them screaming as they chase one another through the house, "the sun, the smell of the air just now, each physical moment passing, passing," as the poet Robert Creeley once said, "it's what it always is or ever was, just then, just there." 
Have you felt that? Or is it just old people like me? Each physical moment passing, passing, just then, just there.

Here we are again, you and I, come to greet another year, another Yom Kippur, nestled here in Bel-Air, just below the Getty, privileged by our geography and by the distinction of our membership. Fences, security guards, several security guards, just for us, we could well live out our lives as a guarded gated community of Jews, absorbed in our own spiritual needs and dedicated solely to the advancement of Jewish learning and religious observance for ourselves and our children and acknowledging our responsibility for the security and well-being of our fellow Jews in Israel, everywhere. Is that what it's all about? Is that what it means to be a Jew, to be a Jew in the twenty-first century? To be absorbed primarily in our needs as Jews? No (it hardly needs be said), that's surely not enough for the Leo Baeck Temple whose spiritual leader is Ken Chasen, and Sandy Ragins before him. Just take a look at this month's Temple Bulletin to see again that the Jewish hearts in this synagogue clearly have a place of significant value for something beyond our Jewish selves.

It's a hard thing talking to you this year. Such a tumult is the world, brimming with anger and adversaries and terror and hatred and fear, great fear everywhere. Why, unlike you and me, does everybody else and everything in this world have to be so complicated? It is confusing. To live in this world, in this irrational time, when the values that we Jews have always affirmed are daily being coarsened, mutilated even, by our own country, even by Jews, is to be confused and angry and frightened. Confusion, anger, and fear seem to me to be thoroughly rational responses to an irrational situation.

Exactly twenty-four years ago, 1982-that was the year that Israel invaded Lebanon-I gave a sermon for Rosh Hashanah evening in the course of which I said that I would be speaking about the war in Lebanon on Yom Kippur. As I stood at the door to greet our members as they left, a good friend of mine, the late Norman Tyre, approached me. Norman frequently had had serious problems with some of the views expressed in my sermons (would you believe that?) [and] never failed to communicate his distress with me, but that in no way impinged on our affection for one another. This time he said: "I'm so glad to hear that you will be talking about the war in Lebanon on Yom Kippur, because I'm gong to be in India." (I have a feeling that some of you might wish to be somewhere else by the time this sermon is done.)

Now in those days I used to keep in my desk drawer a statement by Robert Alter, distinguished professor at Berkeley, which I would take out whenever I felt like being critical of Israel. "Morality on the subject of Israel comes cheap to an American Jew, because he is not directly confronted with the responsibilities of power, the naked needs of survival."

Back then-this will hardly surprise you-I was one of that minority of Jews here who believed, from the very first day, that the war in Lebanon, the war of 
Menachem Begin and General Ariel Sharon, was doomed to be a moral and political failure. About rabbis like me there was a letter written to the American Jewish periodical SH'MA. "God bless our Jewish intellectual liberals (the rabbis among them). God bless them with their Jewish consciences and their Jewish sympathy for the hurt and suffering of all people. God bless them-and keep them far from positions of responsibility. We need their prophetic reminders of who we are and how we should act, but we would have disappeared from the face of the earth if we had let them make the practical decisions of daily existence."

The purpose of that war, Prime Minister Begin solemnly declared, was "to secure peace in the Galilee and when we reach the forty kilometer limit, the fighting will cease." It soon became clear as the Israeli army marched closer to Beirut, that this was a lie. It was well known that Israel had been looking for a pretext for a full-scale war in Lebanon in order to create a new order in Lebanon and to liquidate once and for all the PLO, thus securing Israel's northern border and bringing to submission the Palestinian population of the West Bank and Gaza, having deprived them of their leadership. "To crush, to eradicate, to liquidate, to fumigate, to wipe out" this was the lexicon of Menachem Begin, and as he said in a letter to President Reagan, "we are marching to Berlin to liquidate Hitler." The war did succeed in driving Hitler (Arafat) and the PLO from Lebanon, but it was not the PLO that was destroyed; it was the moral stature of the state of Israel. The massive use of military force, the massacres at the refugee camps at Sabra and Shatila as the Israeli troops stood idly by, not only brought untold suffering to the civilian population; it also supplied credibility to the hostile propaganda that presented Israel as an aggressive state bent on expansion and annexation while trampling on the rights of the Palestinian people. But the war was fought, and the dead died. And the defeated Palestinians strengthened their national will by creating a new martyrology, and 300,000 Israelis would rally in protest in the streets of Tel Aviv, expressing their shock and shame. Abba Eban, once Israel's Ambassador to the United States would say, "This war has been a dark age in the moral history of the Jewish people." The government of Menachem Begin would fall; Begin would disappear from public life. Ariel Sharon was disciplined and prohibited from ever becoming Defense Minister again. (Obviously that didn't apply to becoming Prime Minister.) Eleven years later in this month of September 1993, the defeated Arafat would be standing on the White House lawn with Prime Minster Yitzhak Rabin and President Clinton.

And, as you remember, out of that 1982 war in Lebanon there arose a small extremist organization called The Party of God, Hizbollah, dedicated to the destruction of Israel.

What does our prayer book say? "The Torah has taught us to put our trust not in force and violence, not in aggression and domination, but in justice and truth, in kindness and compassion." How naïve. How naïve.

This new ugly thirty-four-day war in Lebanon has now been fought. Hizbollah crossed the Israeli border, captured (or, if you prefer the locution, kidnapped) two 
Israeli soldiers, killed three others. Israel responded not many days later with a massive attack against the whole of Lebanon. The chief of staff of Israel's army, Dan Halutz, declared that "for every rocket fired by Hizbollah a ten story building will be destroyed. We'll set the country back fifty years. Everything is a target." Most Israelis gave their full support for this war. There were some protesters. Even those who had previously been identified with the peace movement in Israel, intellectual leaders among them, fully supported the war, at least in its initial stage.

Hizbollah, according to Israel and confirmed by Human Rights Watch and Amnesty International, committed war crimes in deliberately targeting civilians with its rockets. But these ruthless acts, which brought death and suffering to Israelis in the north, did not go unmatched by the Israeli army. Although there were indeed occasions when Hizbollah was embedded among civilians, Human Rights Watch and Amnesty insisted that Israel committed war crimes in being indifferent to the lives of civilians in towns and villages where there were no Hizbollah fighters nearby, and in dropping hundreds of thousands of cluster bombs in the closing days of the war, many of which lie still unexploded.

This war, as brutal as it was, trumpeted and believed in by so many Israelis and American Jews as being full of high cause, as an existential threat to Israel, was, in my view, but a new chapter for Barbara Tuchman's March of Folly, one that could comfortably and logically follow our country's folly, its ill-fated war in Iraq, not so strange since Israel and the United States are linked to each other's sometimes poorly considered militant purposes. Or the war could be seen simply as another bloody chapter in the many tragedies in the Middle East, many of which might have been avoided with creative diplomacy and political vision instead of the insistent assertion of military power. Jacques Derrida, one of the outstanding philosophers of our era, wrote of the "autoimmunity crisis" he found rampant in the United States and other countries of the West after 9/11, whereby the defensive system devised to keep out infection (the enemy that is) actually invites it and works against itself.

But the real struggle for Israel's survival, as Zeev Maoz has pointed out, is not the one against Israel's many enemies such as those heard spewing forth in the ranting of Hamas, Hassan Nasrallah of Lebanon, and Mahmoud Ahmadinejad of Iran. The real struggle is one taking place within Israel and within us as American Jews. It is a struggle for the heart and soul, one that has been taking place in Israel from its very beginning, and certainly since 1967, when it conquered all of the territory between the Jordan and the sea. So it has become a struggle about the future of Israel as a moral state. But it is also a struggle about our purpose as American Jews, whether we are just to be Jews, to be supporters of Israel, and our fellow Jews, since all Jews are responsible for one another, to be Jews and to continue to be what we have been, a monument to endurance; or whether we are in any way, more importantly, to be Jews, and to become bearers of a great moral aspiration. Yes, to 
be responsible for our fellow Jews and especially Israel, reveling in its remarkable accomplishments, to be responsible, but not always in the way these members of our Jewish family choose to define themselves, not in ways that bring destruction to others or to themselves.

I shall never forget the words I heard spoken almost thirty years ago by the great Jewish leader Nahum Goldmann, when he said at a meeting I attended in Tel Aviv: "This is a critical hour in the history of Israel and the Jewish people. The great problem for Israel is the problem of being powerful. For two thousand years we were powerless as a people, and without power we learned how to be the best visionaries, the best dreamers, the best idealists. Now the powerless have become powerful. We have an army and flags and a state and victories." (He could have gone on to say, and an air force and nuclear weapons and sophisticated technology, the envy of many nations in the world.) "And in America, Jews are well organized and wealthy and highly placed in all of the realms of political, cultural and economic life. But we have not yet learned how to use our power in the service of our visions. To place our reliance on power is our greatest weakness. The survival of the Jewish people is more in danger today than ever before."

I think we must be on guard against those in the Jewish community whose definition of policy is the assertion of military power. That leads to a shrill militancy in reckoning with anyone with whom we differ, viewing them as enemies of the good, enemies of Israel, anti-Semites. We had a pathetic example of that here in Los Angeles recently, when a group of our respected Jewish organizations, led by the American Jewish Committee and the JFC [Jewish Federation Council of Los Angeles], engaged in a public campaign of vilification and humiliation of one of the most respected leaders of the Muslim community, Dr. Maher Hathout, my friend of almost twenty years, who had been named to receive an honor from the Los Angeles County Human Relations Commission. Why? Because he had been critical of Israel, because he had said some outrageous things about Israel and therefore, they insisted, he had been masquerading as a moderate. He had dared to call Israel an apartheid state. Dr. Hathout should have simply read aloud the words of Michael Ben-Yair, Israel's Attorney General from 1993 [to] 1996, who wrote: "After the 1967 war we enthusiastically chose to become a colonial society, ignoring international treaties, expropriating lands, transferring settlers from Israel to the Occupied Territories ... Passionately desiring to keep these territories, we developed two judicial systems: one-progressive, liberal-in Israel; and the other-cruel, injurious-in the Occupied Territories. In effect, we established an apartheid regime in those territories."

This being a day for acknowledging our sins it is a day to be reminded that there is one sin (as my friend the late William Sloane Coffin once said) that locks people up in all other sins, and fastens them more tightly than ever in their predicaments. It's the sin of self-righteousness. Self-righteousness is trouble enough in a single 
human being, but when it afflicts a nation, it spells enormous danger. Hope for a different kind of world is not to be found in an America or an Israel that will stand tall. No, it is to be found in the capacity to yield a little of our self-righteousness, repenting, just a little, for the cruelties brought to the innocent. Bill Coffin said it so well: "If only we wouldn't go on using the conspicuous wrong-doing of our adversaries as a means of nourishing our own self-righteousness, instead of permitting the wrongs to deepen our awareness that we are all in need of some repentance, some humility."

We need some humility, but we also need a far greater, wider, brighter vision of what it can mean to be a Jew. Israel's first Chief Rabbi, Abraham Isaac Kook, once said that there are many rungs in the ladder of perfection which must be climbed before the height of a truly universal human being is reached. "There are those who sing the song of life and in themselves find everything. There are others who sing the songs of their people. They leave the circle of private existence for they do not find it broad enough ... they attach themselves with tender love to the whole of Israel, sing her songs, grieve her afflictions and probe the content of her inner essence. Then there are those whose spirit extends beyond the boundary of Israel to sing the song of humanity and this is the life source from which they draw their thoughts and their yearnings and visions. But there are those who rise even higher, uniting themselves with the whole of existence, with all creatures, all worlds. It is of such that the tradition has said that whosoever sings a portion of this universal song each day is assured a life in the world to come."

This is Yom Kippur, and the spirit of Yom Kippur has no boundaries. It sees repentance as the most creative force in the universe. It comes to tell us that life can be a time that we throw off our helplessness and that we can be the bearers of love and forgiveness, of compassion and hope.

Listen, my friends. One-two-three-each physical moment passing, passing, just then, just there. We can't make time stand still. The mind will be paralyzed that tries to make time stand still. But what will sustain us is to uphold an image of hope and beauty. The sun is here. Life and the earth in all their complexity are here. And before us the great mystery before which we all stand equally. I see the people standing in Tyre, Sidon, and Beirut; I see them in Kiryat Shemona and Jerusalem; I see them in Ramallah, and in Kalkilya, in Isfahan and Teheran, in Baghdad; I see them in Watts and here in Bel-Air, all standing equally before the great mystery, in awe and in ignorance. In this ultimate humility the human spirit can find a home, a place of safety.

Al tira, do not be afraid. Al tira, the commandment that appears more frequently in our Bible than any other. Al tira, do not be afraid.

One-two-three-each physical moment-just then-just there.

AMEN 


\section{COMMENTARY BY RABBI BRANT ROSEN}

In this sermon and subsequent exchange, we can clearly see Rabbi Beerman's unique ability to combine an unwavering insistence on justice with a deep and abiding empathy.

In 2006, this rabbi stood before his congregation on Yom Kippur and agreed with a human rights organization's claim that Israel had committed war crimes. Even as I write these words ten years later, it is fair to say that most rabbis would never be able to say such things and keep their jobs-even if they believed such things to be true. Those who knew Rabbi Beerman know well that he was able to say such things because of the trust he had for the members of his congregation.

There can be no better evidence of this trust than the final paragraphs of his sermon. This was not, in the end, a sermon about Israel's actions in Lebanon. It was, in Rabbi Beerman's own words, a sermon about humility, love, forgiveness, compassion, and hope. Thus even a congregant who violently disagreed with Rabbi Beerman's views was still able to respond to his words with "unconditional love."

According to a famous midrash, when God created the world, God said, "If I create the world with the attribute of compassion alone, its sins will be too many; if with justice alone, how could the world be expected to endure? So I will create it with both justice and mercy, and it may endure!"

Rabbi Leonard Beerman was that unique moral leader who was able to combine justice and compassion. And this is why his rabbinate endured. 